\title{
Jumping spiders of the genus Icius Simon, 1876 (Araneae: Salticidae) from India, with a description of a new species
}

\author{
Пауки-скакунчики рода Icius Simon, 1876 (Araneae: Salticidae) \\ из Индии, с описанием нового вида
}

\author{
John T.D. Caleb \\ Ажкон Т.А. Камеб \\ Zoological Survey of India, Prani Vigyan Bhawan, M-Block, New Alipore, Kolkata-700 053, West Bengal, India. Email: \\ caleb87woodgate@gmail.com
}

KEY WORDS: Diagnosis, distributional map, new combination, South India.

КЛЮЧЕВЫЕ СЛОВА: Диагноз, карта распространения, новая комбинация, Южная Индия.

ABSTRACT. The genus Icius is recorded from India for the first time. A new species of jumping spiders, Icius kumariae sp.n. ( $\mathrm{O}^{7}+$ ), is described from South India. A detailed description and illustrations of both sexes are provided. A new combination is proposed: Icius alboterminus (Caleb, 2014) comb.n., ex Phintella.

How to cite this article: Caleb J.T.D. 2017. Jumping spiders of the genus Icius Simon, 1876 (Araneae: Salticidae) from India, with a description of a new species // Arthropoda Selecta. Vol.26. No.4. P.323327. doi: $10.15298 /$ arthsel.26.4.07

РЕЗЮМЕ. Род Icius отмечается в фауне Индии впервые. Из Южной Индии описан новый вид пауков-скакунчиков, Icius kumariae sp.n. (○7\%), для которого приведятся детальное описание и рисунки обоих полов. Предлагается новая комбинация: Icius alboterminus (Caleb, 2014) comb.n., ex Phintella.

\section{Introduction}

The jumping spider genus Icius was erected by Simon in 1876 . In the world fauna, it currently consists of 34 species, including 18 species from Africa, 7 from Asia (3 species are known from China, one from Afghanistan, one from Sumatra, one from Japan and one is a widespread Palaearctic species), five from Europe (including one recorded from the lower reaches of Volga River in Russia), three from the Americas and one from Micronesia [WSC, 2017]. To date, the genus has not been formally recorded from India. This paper presents a description of a new species Icius kumariae sp.n. $\left(\mathrm{O}^{7}+\right.$ ) that was discovered in the vicinity of Thirumullaivoyal near Araabath Lake, Chennai and NCBS campus, Bengaluru, South India. A new combination is also proposed for Phintella alboterminus Caleb, 2014 originally described and known from the same region.

\section{Materials and methods}

Specimens were hand collected from tree bark. Live specimens were photographed by means of Nikon D90, $18-55 \mathrm{~mm}$. Then the specimens were preserved in 70\% ethanol and examined under a Leica S8APO stereoscopic microscope. Micro-photographs were obtained by means of a Leica MC120 HD camera attached to the stereoscopic microscope, with the LAS core software package. All measurements are in millimeters. Leg measurements are given as follows: total length (femur, patella, tibia, metatarsus, tarsus). The description of colour characters is based on fresh specimens. Leg spination pattern follows Davies [1994]. Type specimens are deposited in the National Centre for Biological Sciences, Bengaluru, Karnataka, India (NCBS) and Zoological Survey of India, Kolkata, West Bengal, India (ZSI-CDT).

Abbreviations used in the text are as follows: ALE anterior lateral eye, AME - anterior median eye, PLE - posterior lateral eye, PME - posterior median eye, RTA — retrolateral tibial apophysis.

\section{Taxonomy}

\section{Icius Simon, 1876}

Type species: Icius hamatus C.L. Koch, 1846.

DIAGNOSIS. For diagnostic features and redescription of the genus, see Alicata, Cantarella [1994].

\section{Icius kumariae sp.n.}

Figs 1-19, Map.

TYPES. Holotype male (NCBS, AW264) from India, Tamil Nadu, Chennai, Thirumullaivoyal $\left(13^{\circ} 7^{\prime} 30.327^{\prime \prime} \mathrm{N}, 80^{\circ} 8^{\prime} 8.523^{\prime \prime} \mathrm{E}\right)$, $24 \mathrm{~m}$ a.s.1., 17.10.2016, J.T.D. Caleb.

Paratypes. INDIA: $1 \sigma^{7}, 1$ (NCBS, AW265-266), Tamil Nadu, Chennai, Thirumullaivoyal $\left(13^{\circ} 7^{\prime} 30.327^{\prime \prime} \mathrm{N}, 80^{\circ} 8^{\prime} 8.523^{\prime \prime} \mathrm{E}\right)$, 26.10.2016, J.T.D. Caleb \& K. Caleb; $20^{7} 0^{7}$ (NCBS, AW267- 

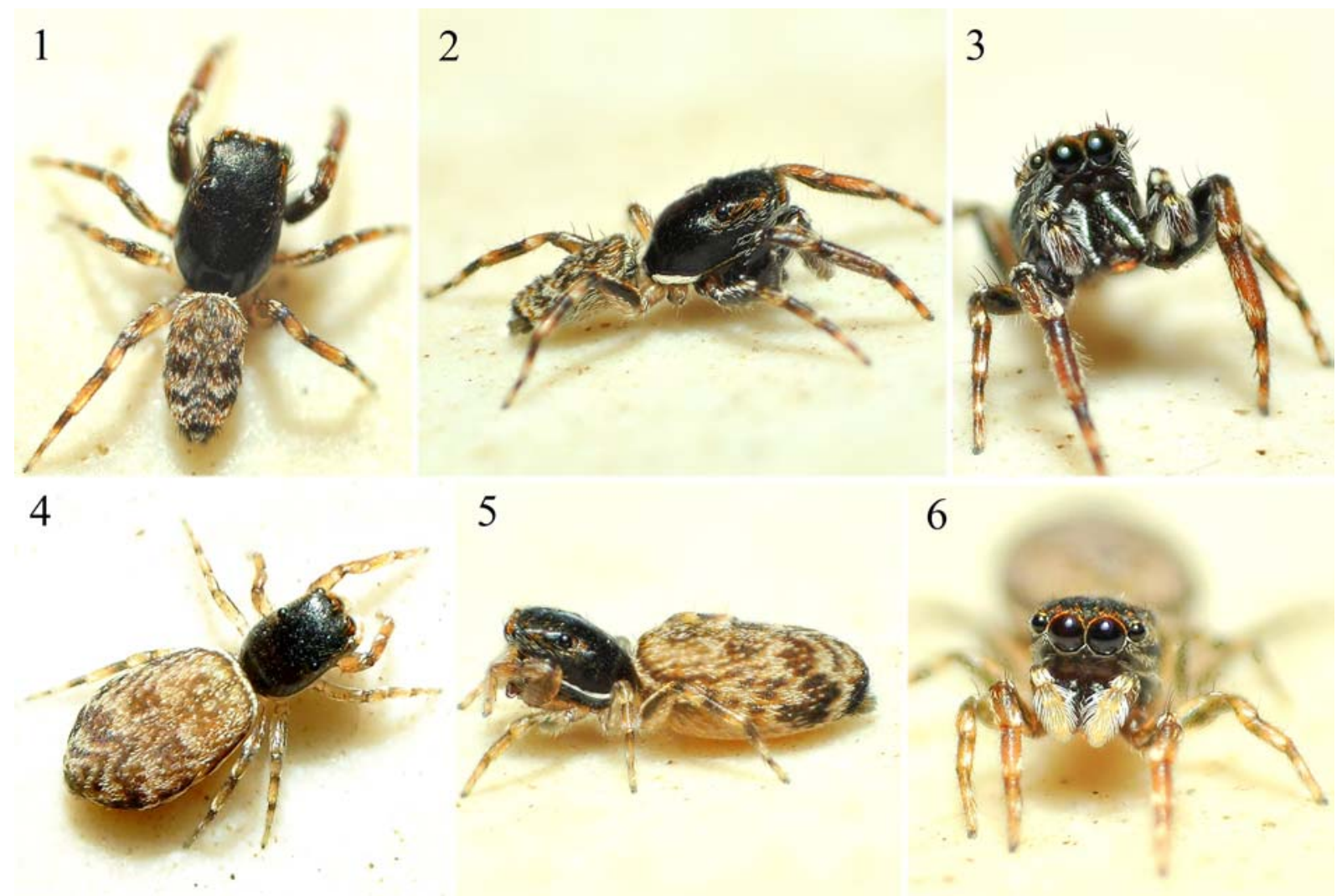

Figs 1-6. General appearance of Icius kumariae sp.n. 1-3 - male, dorsal, lateral and frontal views; 4-6 - female, dorsal, lateral and frontal views.

Рис. 1-6. Общий вид Icius kumariae sp.n. 1-3 - самец, виды сверху, сбоку и спереди; 4-6 - самка, виды сверху, сбоку и спереди.

268), 1 (NCBS, AW269), the same locality, 28.10.2016, J.T.D. Caleb \& K. Caleb; $1 O^{\text {T}}$ (ZSI-CDT, AA1215), the same locality, 1.07.2017, J.T.D. Caleb \& K. Caleb; 1 + (NCBS, AW270), Karnataka, Bengaluru, NCBS campus $\left(13^{\circ} 4^{\prime} 20.7048^{\prime \prime} \mathrm{N}, 77^{\circ} 34^{\prime}\right.$ 46.8156"E), 931 m a.s.l., 18.12.2016, J.T.D. Caleb \& R. Sanap.

ETYMOLOGY. The new species is dedicated to my wife, Kumari Caleb.

DIAGNOSIS. The new species can easily be distinguished from its sympatric congener Icius alboterminus (Caleb, 2014) comb.n., by the general dorsum pattern having no white spots (abdomen with two pairs of distinct white spots in I. alboterminus; cf. Figs 1 and 4 with figs 1 and 6 in Caleb [2014]). Both species also differ significantly in their copulatory organs (embolus short and thick; RTA single; epigyne with anteriorly placed copulatory openings and longer insemination ducts in I. alboterminus, cf. Figs 16-19 herein with figs 9-12 in Caleb [2014]). By the palpal morphology, the new species seems to be similar to Icius rugosus Suguro et Nagano, 2015, from which it can be separated by the broader embolic base and the lightly bent embolus (Figs 10, 16), as well as by the unique shape of RTA, with two projections of almost equal heights (Figs 11, 12, 17). The female of Icius kumariae sp.n. can be easily distinguished from those of other congeners in having the closely placed, posterio-median cop- ulatory openings (Figs 13, 15, 18) and the insemination ducts short, making a single loop before reaching the spermathecae (Figs 15, 19).

DESCRIPTION. MALE (holotype). Total length: 2.15, carapace: 1.03 long, 0.68 wide; abdomen: 1.12 long, 0.69 wide. Carapace black, covered with greyish hairs; sparse hairs tinged with golden to rusty brown present along the lateral eye margin (Figs 1,2). AMEs are surrounded by reddish orange orbital setae in the upper half and white orbital setae in the lower half. About 6-7 elongated leaf-like long hairs present behind ALEs; similar series of short hairs present behind AMEs. Clypeal region blackish (Figs 3), two parallel thin patches of white hairs extend shortly backwards from the cheek region to the lateral margins below PLEs. Outer edge of carapace with a thin stripe of white hairs. Eye measurements: AME 0.17, ALE 0.09, PME 0.02, PLE 0.06. AME-AME 0.01, AME-ALE 0.01, ALE-PME 0.11, PLE-PLE 0.42, PME-PME 0.48, PME-PLE 0.08. Clypeus height 0.05. Sternum oval, dark brown, covered with greyish hairs. Chelicerae unidentate, dark brown; labium and maxillae brownish (Fig. 9). Legs yellowish with brownish annulations on the proximal part of each segment; white patches of hairs at distal ends. Femur I blackish, femur II-IV with 

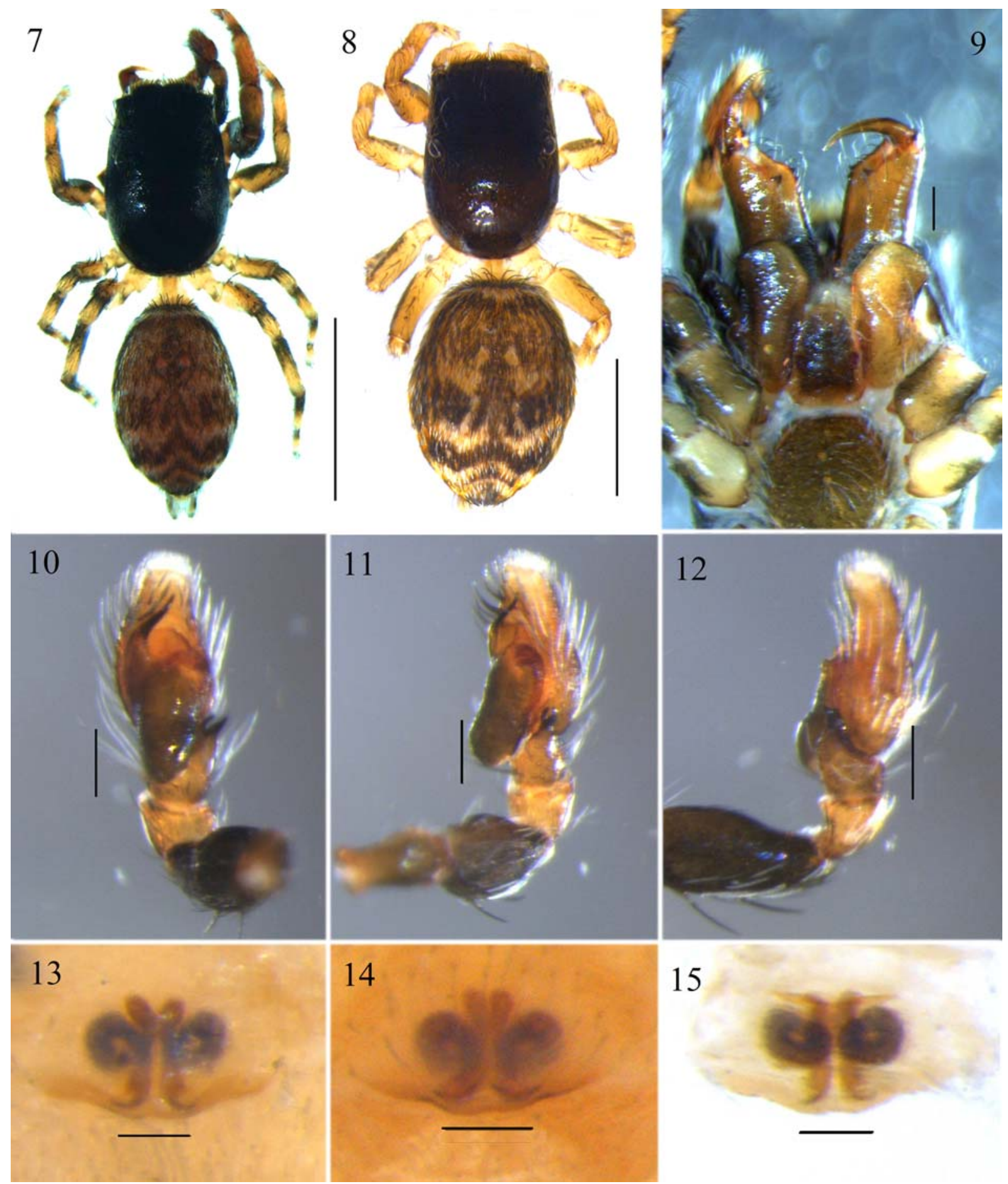

Figs 7-15. General appearance and copulatory organs of Icius kumariae sp.n. 7 - male, dorsal view; 9 - male chelicerae, retrolateral view; 10 - male left palp, ventral view; 11 - ditto, ventro-lateral view; 12 - ditto, retrolateral view; 8 - female, dorsal view; 13 epigyne, paratype (NCBS, AW265), ventral view; 14 - spermathecae, dorsal view; 15 - epigyne, paratype (NCBS, AW269), ventral view. Scale bars: $1 \mathrm{~mm}(7,8) ; 0.1 \mathrm{~mm}(9-15)$.

Рис. 7-15. Общий вид и копулятивные органы Icius kumariae sp.n. 7 - самец, вид сверху; 9 - хелицера самца, вид сзадисбоку; 10 - левая пальпа самца, вид снизу; 11 - тоже, вид снизу-сбоку; 12 - тоже, вид сбоку-сзади; 8 - самка, вид сверху; 13 эпигина, паратип (NCBS, AW265), вид снизу; 14 - сперматека, вид сверху; 15 - эпигина, паратип (NCBS, AW269), вид снизу. Масштаб: 1 мм (7, 8); 0,1 мм (9-15). 


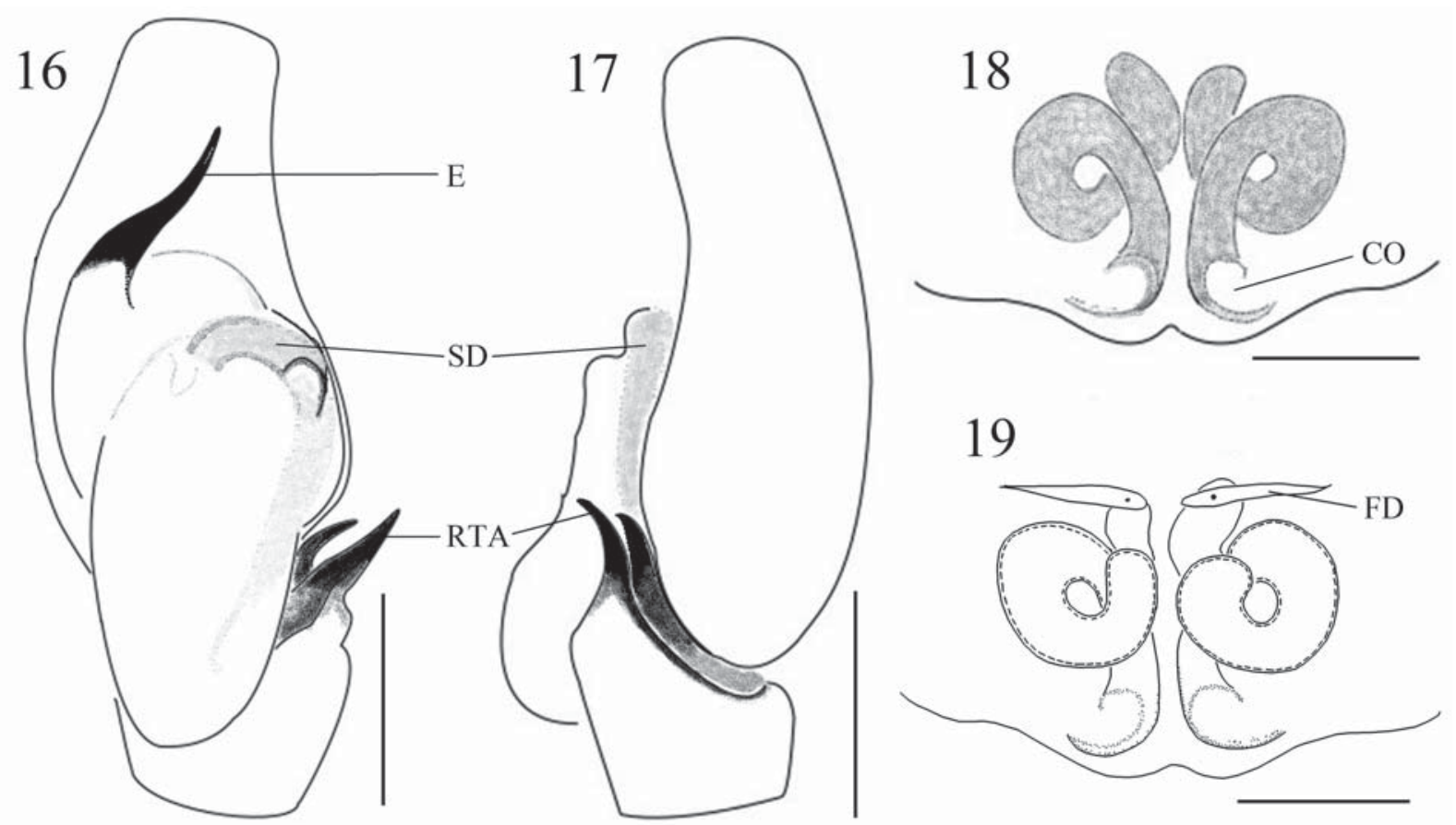

Figs 16-19. Copulatory organs of Icius kumariae sp.n. 16 - male left palp, ventral view; 17 - ditto, retrolateral view; 18 - epigyne, ventral view, 19 - spermathecae, dorsal view. Scale bars: $0.1 \mathrm{~mm}$ (16-19). Abbreviations: CO - copulatory opening, E - embolus, FD fertilization duct, RTA — retrolateral tibial apophysis, SD — seminal duct, T — tegulum.

Рис. 16-19. Копулятивные органы Icius kumariae sp.n. 16 - левая пальпа самца, вид снизу; 17 - тоже, вид сзади-сбоку; 18 эпигина, вид снизу, 19 - сперматека, вид сверху. Масштаб: 0,1 мм (16-19). Сокращения: СО - копулятивное отверстие, Е эмболюс, FD: оплодотворительный канал, RTA - заднебоковой тибиальный отросток, SD - семенной канал, T - тегулум.

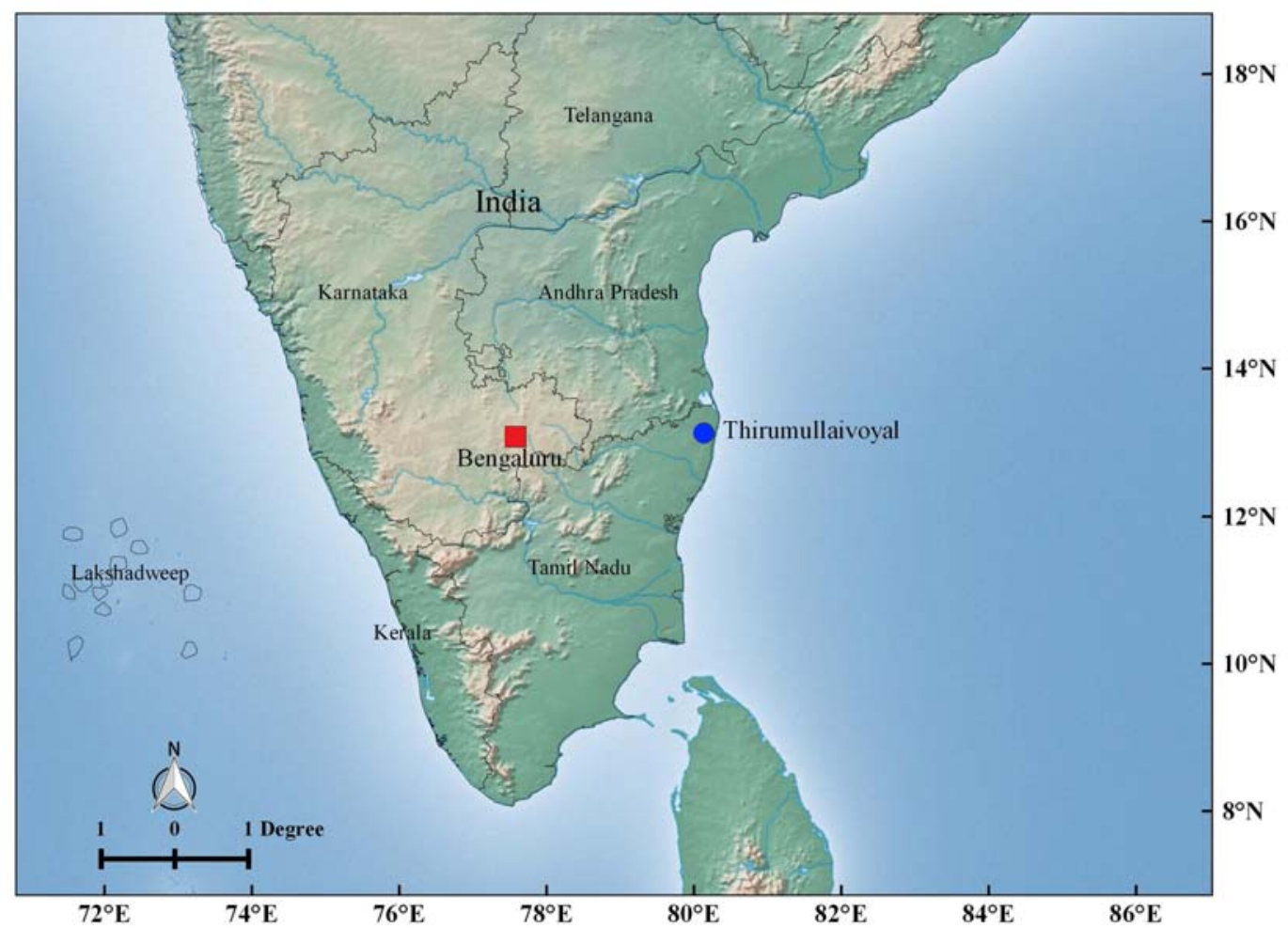

Map. Collecting records of Icius species in India: Icius alboterminus (Caleb, 2014) (blue circle) and I. kumariae sp.n. (blue circle and red square).

Карта. Точки находок видов Icius в Индии: Icius alboterminus (Caleb, 2014) (голубой кружок) and I. kuтariae sp.n. (голубой кружок и красный квадрат). 
blackish lateral longitudinal patches, covered with white hairs (Figs 1-3, 7). Leg measurements: I 1.61 (0.50, $0.33,0.36,0.25,0.17)$; II $1.23(0.40,0.22,0.25,0.20$, $0.16)$; III $1.21(0.39,0.20,0.22,0.21,0.19)$; IV 1.57 $(0.51,0.25,0.32,0.28,0.21)$. Leg spination: femora I 2300; II 0300, III 0300, IV 0300; tibiae I 1001, II 0000, III 0001, IV 0000; metatarsi I 0004, II 1001, III 0011, IV 0011. Abdomen elongated-oval; dark brown, clothed with white hairs making chevron-shaped markings; rusty brown to orangish hairs interspersed; posterior tip of abdomen black; venter yellowish-brown uniformly. Spinnerets brownish; covered with a small patch of white hairs dorsally (Figs 1-3, 7). Palp covered with white and yellowish hairs; embolus long with a broad base, arising at 10 o'clock, gently bending apically; bulbus projects posteriorly (Figs 10, 16); RTA with two, closely situated branches and with a broad base tapering toward the tip; the inferior apophysis is slightly shorter (Figs 11, 12, 17).

FEMALE (NCBS-AW265). Total length 3.20, carapace: 1.44 long, 0.97 wide; abdomen: 1.76 long, 1.20 wide. Eye measurements: AME 0.28, ALE 0.14, PME 0.02, PLE 0.12. AME-AME 0.01; AME-ALE 0.02, ALE-PME 0.33, PLE-PLE 0.71, PME-PME 0.76, PMEPLE 0.14. Clypeus height 0.03. Leg measurements: I $1.80(0.58,0.38,0.36,0.25,0.23)$; II $1.67(0.55,0.34$, $0.30,0.27,0.21)$; III $1.77(0.56,0.28,0.32,0.35,0.26)$; IV $2.47(0.80,0.39,0.52,0.48,0.28)$. Leg spination: femora I 4300; II 0300, III 0300, IV 0300; tibiae I 0002, II 0001, III 0000, IV 0000; metatarsi I 0004, II 0003, III 1000, IV 1001. Colour pattern as in the male, but the general body coloration is slightly dull (Figs 4$6,8)$. Epigyne simple, with posterio-median copulatory openings; the posterior margin of epigyne and copulatory openings more sclerotized than the epigynal plate (Figs 13, 14, 18); insemination ducts short, making a single loop (Figs 15, 19).

DISTRIBUTION. India: Tamil Nadu (Thirumullaivoyal), Karnataka (Bengaluru) (Map).

\section{Icius alboterminus (Caleb, 2014) comb.n.}

Phintella alboterminus Caleb, 2014: 605, Figs 1-12 (description of male \& female) (type deposited in ZSI-SRC, examined [Reg. no. ZSI-SRC-I/SP 10-11)

REMARKS. Phintella alboterminus Caleb, 2014 was described on the basis of the specimens collected from the vicinity of Araabath Lake, Thirumullaivoyal. It was incorrectly placed in the genus Phintella by Caleb [2014]. Prószyński \& Caleb [2015] provisionally proposed a transfer of this species to Icius, based on general body morphology and the conformation of the copulatory organs. A new combination is thus formally proposed here.

ACKNOWLEDGEMENTS. I thank Dr. Krushnamegh Kunte of the National Centre for Biological Sciences (NCBS) for allowing me to use their stereomicroscope facility and to deposit the studied specimens. Special thanks go to Rajesh Sanap for initiating field collecting at the NCBS campus, Bengaluru. I thank the American Arachnological Society for an Arachnological research grant from the Herbert Levi fund (HLMFAR). Finally, I am greatly indebted to my parents, David and Udaya Prasanna for their constant encouragement and financial support. Sincere thanks go to Dr Dmitri Logunov (Manchester, UK) for providing constructive comments on the ms that helped to improve it.

\section{References}

Alicata P., Cantarella T. 1994. The Euro-Mediterranean species of Icius (Araneae, Salticidae): a critical revision and description of two new species // Animalia. Vol.20. P.111-131.

Caleb J.T.D. 2014. A new species of Phintella Strand (Araneae: Salticidae) from India // Munis Entomology and Zoology. Vol.9. No.2. P.605-608.

Davies V.T. 1994. The huntsman spiders Heteropoda Latreille and Yiinthi gen. nov. (Araneae: Heteropodidae) in Australia // Memoirs of the Queensland Museum. Vol.35. P.75-122.

Prószyński J., Caleb J.T.D. 2015. Identification key of Salticidae (Araneae) of the Indian Subcontinent; online at: http:// www.peckhamia.com/salticidae/ index_India.html (accessed on 28 July 2017).

Simon E. 1876. Les arachnides de France. Paris. Vol.3. P.1-364. Suguro T., Nagano H. 2015. A new species of the genus Icius (Araneae: Salticidae) from the Ogasawara Islands, Japan // Acta Arachnologica. Vol.64. No.2. P.91-95. doi:10.2476/asjaa.64.91

WSC 2017. World Spider Catalog (version 18.5). Natural History Museum Bern; online at: http://wsc.nmbe.ch (accessed on 18 August 2017).

Responsible editor D.V. Logunov 